Canadian University Music Review

Canadian University Music Review

Revue de musique des universités canadiennes

\title{
Healey Willan's Inscribed Copy of John Coulter's Deirdre of the Sorrows
}

\section{Rita Steblin}

Volume 12, numéro 1, 1992

URI : https://id.erudit.org/iderudit/1014214ar

DOI : https://doi.org/10.7202/1014214ar

Aller au sommaire du numéro

Éditeur(s)

Canadian University Music Society / Société de musique des universités canadiennes

ISSN

0710-0353 (imprimé)

2291-2436 (numérique)

Découvrir la revue

Citer cet article

Steblin, R. (1992). Healey Willan's Inscribed Copy of John Coulter's Deirdre of the Sorrows. Canadian University Music Review / Revue de musique des universités canadiennes, 12(1), 113-122. https://doi.org/10.7202/1014214ar

All Rights Reserved (C Canadian University Music Society / Société de musique des universités canadiennes, 1991
Ce document est protégé par la loi sur le droit d'auteur. L'utilisation des services d’Érudit (y compris la reproduction) est assujettie à sa politique d'utilisation que vous pouvez consulter en ligne.

https://apropos.erudit.org/fr/usagers/politique-dutilisation/ 


\title{
HEALEY WILLAN'S INSCRIBED COPY OF JOHN COULTER'S DEIRDRE OF THE SORROWS*
}

\author{
Rita Steblin
}

The recent discovery of a small item of Canadiana is interesting not only for its musical importance but also for the human touch it reveals in one of the great composers of our musical past. The item in question is a copy of John Coulter's libretto Deirdre of the Sorrows (Toronto: Macmillan, 1944), signed by both Coulter and Healey Willan, and containing thirty-six musical excerpts from Willan's three-act opera of the same name, written out in the margins in the composer's neat hand. ${ }^{1}$ (See the illustration.) This was clearly a labour of love, and in fact Willan has written on the front flyleaf "For Corinne - who understands. - 31:vii:45." However, inquiries concerning the identity of the mysterious Corinne have resulted only in a vague description of an attractive, somewhat plump, brunette English pianist who spent the war years in Toronto. ${ }^{2}$ It is also a puzzle how this inscribed libretto, if meant as a gift, ended up in Willan's effects after his death. It was found there in 1968 by the composer's son Patrick, who kept it as a memento of his father. Thus it was separated from the rest of Willan's estate, the bulk of which is now at the National Library of Canada in Ottawa. This annotated libretto was sold in late 1989 to a bookseller in Victoria, B.C., who brought it to the Vancouver Antique Book Fair in March 1990. The present author could not bear to abandon such a rare item to an unknown fate, and after much thought, purchased the book.

Willan's opera Deirdre of the Sorrows is of twofold significance: it was the first full-length Canadian opera commissioned by the CBC, and it was regarded by the composer himself as his most important work. The opera is based on an

* This article is dedicated to my Grade 7 teacher in Richmond, B.C., Deirdre Gilhuly Nowicki, who was sympathetic to a child of East European refugees, and who impressed upon me the sorrowful nature of her name.

1 The excerpts are written in two different inks, changing from a darker blue to a lighter blue at the beginning of Act III. Carefully taped inside the front and back covers are cuttings from the book's dust cover as well as two newspaper clippings announcing the completion of the opera and the threehour CBC broadcast of the work on April 20, 1946.

${ }^{2}$ I wish to thank all those who helped me in my pursuit of the illusive Corinne, including William Aide, Boris Berlin, Giles Bryant, F.R.C. Clarke, Margaret Drynan, Margaret Gillespie, Margaret Harmer, Peter Haworth, Helmut Kallmann, Dorothea Link, Mary Mason, and Stephen Willis. 


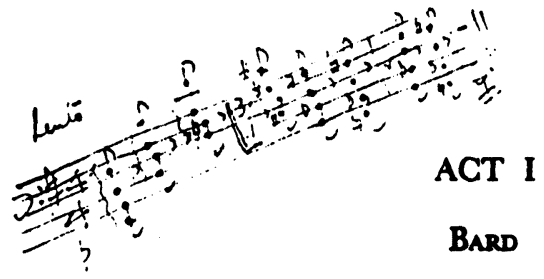

Before each scene he appears in front of the curtain, carrying a harp. Having sung of what is to follow he moves off, and the curtain opens.

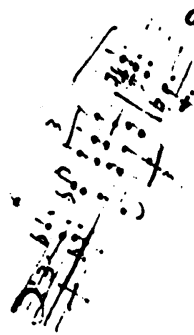

Now to the music of plucked strings I sing again, a story that northern bands had sung for nigh two thousand years: of Conochar, king of Ullah, and of the foundling girl his ward: that Deirdre of the Sorrows

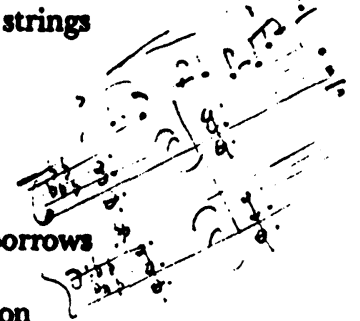
who in a druid prophesy was doomed to bring destruction upon the men who loved her and who by her were loved:

Naisi, son of Usnagh, and his brothers, Ainnle and Ardan.

In the woods by Conochar's dun, the palace of Avan Macha,

it is a night of violent storm. and a sacred tree, Cathva the arch-druid and his druid priests if go slowly circling. They chant a druid incantation calling out to the gods to spare a kingdom. Near by unseen by the circling priests the king is sheltering. Fergus

Figure 1 
ancient Irish tale of the Red Branch Knights of Ulster and tells the legendary story of the tragic Deirdre - a subject particularly appropriate since both Coulter and Willan were of Irish extraction (transplanted to Toronto), with strong patriotic love for Britain. And this was wartime. As Coulter wrote in his memoirs:

We hoped ... for some immemorial myth or fable, the outcry of the heart in turmoil with the passions of love and death, vulnerable heroic man against the implacable fates. This seemed to us the true domain of opera; at any rate it was the domain in which Healey's musical imagination could roam with rewarding delight (Coulter 1980: 178).

Willan, in turn, was moved by Coulter's eloquent, poetic language, and would ask the poet to read his lines aloud so as to get the inflections right. He often stated that the words were so beautiful that the music wrote itself. In a radio talk about the opera, he testified to the power of the text as follows:
A story that northern bards have sung for nigh two thousand years ... of the willful and masterful King Conochar, of Cathva, the Druid High Priest, of the lovely Deirdre and the handsome Prince [Naisi], spies, fighters, keening women, love scene, intrigue, battle and death - until the shuttle's empty and the pattern finished in the figured web the gods were weaving.' What more ingredients could the heart of poet or composer desire? John Coulter has taken all these characters and incidents, and like a skillful chess player, has made his moves with unerring and ominous precision until Cathva's great outburst 'The gods have spoken!' closes the story (Willan 1951).

Theirs was a classic collaboration!

The opera was composed between September 1943 and May 1945 and received its radio première on April 20, 1946, with Ettore Mazzoleni conducting and Frances James singing the title role. A slightly revised version was broadcast by the CBC Opera Company on October 10, 1951, with Geoffrey Waddington conducting. Extensive revisions were undertaken in 1962 and 1964-65 to create a stage version of the opera, renamed Deirdre: the original long passages for bard-narrator were cut, new orchestral interludes were written to accompany scene changes, and much of the music was recomposed to suit the new, shortened rendition of the text. This later version received three performances in April 1965 by the Royal Conservatory Opera School; it was a box-office success in the fall of 1966 at Toronto's O'Keefe Centre when staged by the Canadian Opera Company as its first Canadian opera; and it was produced again in 1972 at the Banff Festival of the Arts. ${ }^{3}$

\footnotetext{
${ }^{3}$ See the detailed account of the performance history of this opera in Cooper 1983: 1089-93.
} 
This opera was not the first collaboration between Willan and Coulter. In 1941 Willan wrote incidental music for Coulter's radio play Conochar's Queen, which served as the basis for Deirdre of the Sorrows; the main leitmotifs of the opera were, in fact, written for this earlier work (Clarke 1983: 158). In 1942 the two men wrote the one-hour opera for radio, Transit through Fire, a social documentary which has been described by Coulter as dealing with

the plight of young people during the years of the Depression, emerging from school or university or apprentices' bench and finding themselves sunk in frustration and despair because of inability to find a place in society, until needed to fight a war (Coulter 1980: 173).

Coulter feared that the libretto, "which scourged the inhumanities of the business world during the Depression," would be censored for its "socially sensitive subject," but the text was approved and the production was a success. The work has recently been described as "dated. The text is so directed to 1942 that it would prove an embarrassment if performed now" (Clarke 1983: 118). Perhaps the work may yet find currency when the present generation of university graduates realizes that it is suffering a similar plight.

While the subject matter of Deirdre is timeless, the opera was criticized for its out-of-date musical style. William Littler, writing in 1966, said about the work:

It may be tempting to wonder what Deirdre might have meant had Healey Willan composed it a half century earlier ... But facts are facts. Deirdre was composed not in 1896 but mostly in 1946 . And today it sounds old, very old, and very much out of joint with contemporary operatic writing (Littler 1966). ${ }^{4}$

Willan, schooled in the post-romantic British tradition of Elgar and Delius, counted himself in the Wagnerian camp: "I make no bones about it: I am an ardent Wagnerian"' (Willan 1966). ${ }^{5} \mathrm{He}$ felt that Wagner's chromatic musical language, with its pervasive leitmotif technique, was the most suitable idiom for setting the myth of Deirdre. In a talk for the 1951 broadcast, Willan defends his use of this conservative style against his critics:

Ibelieve strongly in the leitmotif principle of operatic writing - the principle which admits of a definite theme or progression of chords connected with a person or an event. I am fully aware of the fact that this is considered old-

${ }^{4}$ Quoted in Cooper 1983: 1180.

${ }^{5}$ Quoted in Cooper 1983: 1108. See also the discussion of Wagner's influence on Willan's style in Clarke 1983: 133, 261. 
fashioned and effete by some of the intelligentsia, as they are pleased to dub themselves, and even Ernest Newman referred to it as a system in which each character presented his visiting card before venturing to sing his or her part. But in spite of this, I am of the opinion that the scheme laid out in such colossal proportions and with such consummate artistry by Wagner will live and be a vital force in opera long after his detractors are dead, buried and forgotten (Willan 1951).

Time has passed and this opera no longer needs to prove an avant garde pretension. As the pride and joy of the "Dean of Canadian composers," this opera can stand on its inherent musical merits. Willan's credo was to create beauty, ${ }^{6}$ and beauty is timeless.

Willan was a fluent, prolific composer who prided himself on his craftsmanship. According to Coulter, "Healey - a touch of his genuine modesty in self-appraisal - habitually referred to himself as craftsman, apparently valuing the thought of himself as skilled artisan in music rather than inspired artist" (Coulter 1980: 194). Willan says as much in his own account of how he rewrote the opera for the revised, staged version:

Wherever I was obliged to cut, I naturally had to compose special transitions. That's where workmanship comes in. The joins have got to be clean. If I have done my work properly, you shouldn't be aware of the joins, and the musical fabric should hold together harmoniously and flow smoothly (Opera Canada 1966: 31).

And yet, Willan was also an inspired artist, a creative genius, who wrote his best works when challenged - inspired - that is. His Introduction, Passacaglia and Fugue in E flat Minor (1916), which has been lauded as the greatest organ work since J.S. Bach (Bonnet 1941), ${ }^{7}$ was written to counter the claim that only a "German philosophical mind" could write such complex organ works as Max Reger's Passacaglia in DMinor. Willan certainly rose to the challenge! His great choral masterpiece, An Apostrophe to the Heavenly Hosts (1921), was written under extreme time constraints. Willan himself told the anecdote of how he was suddenly forced to take three days' leave of absence from the Conservatory and, drawing inspiration in a novel way -imagining how he would like to hear the text

${ }^{6}$ In an interview narrated by Godfrey Ridout and recorded in Anthology of Canadian Music: Healey Willan 1982 Willan states: "I am a lover of beauty. I love beautiful things, I love beautiful poems, beautiful pictures, beautiful music ... . But, I find so much music written today is unbeautiful, and it sounds to me uncouth."

${ }^{7}$ Quoted in Clarke 1983: 58, 182-83. According to Bonnet, "this work does the greatest honour to the organ literature of our time." 
sung if he were listening in Massey Hall - completed the work with a day to spare (Ridout 1959: 9-10).

It is less known, perhaps, that Willan was also inspired and motivated by reasons of the heart. Romantic that he was, it is understandable that he sought his muse in the companionship of beautiful women. A particularly intense love affair in the years 1940-41 led to a spate of song writing - beautiful settings of fervent love poems, including one translated from the medieval French by the lady involved (a member of his church choir), whom he code-named (in Elgarian fashion) "Ysobel." 8 According to a recent communication from "Ysobel," she was with him when he wrote the leitmotifs for Conochar's Queen - the material which was to form the musical essence of Deirdre. ${ }^{9}$ If Wagner was inspired by his love for Mathilde Wesendonck to write settings of her poetry, employing musical materials which later appeared in Tristan und Isolde, then surely Canada's self-acclaimed Wagnerian could be similarly inspired. Why hide such colourful history?

The inspiration does not end with "Ysobel," though, who initiated a nine-year hiatus in the relationship in 1942. Coulter writes in his memoirs that

Healey, though busy with his piano concerto for a young pianist whom he admired, Agnes Butcher, was at work on the opera by September [1943], declaring himself so stirred by the story that it had carried him away and was making its own music, as it were dictating to him what he should write. 'I am in love with Deirdre,' he said (Coulter 1980: 180).

In a radio address Willan gave a slightly different sequence of events, saying that he stopped half-way through the second act of Deirdre to write the piano concerto (Willan 1951). The condensed score of the concerto was completed 24 March 1944. Agnes Butcher, to whom the concerto is dedicated, premiered it in August 1944 in a radio performance from CBC Montreal with an orchestra under Jean-Marie Beaudet. It was later recorded with the same performers for release as the first CBC recording of Canadian music. She gave the first public performance of the work in November 1944.

F.R.C. Clarke, in his biography of Willan, describes a "curious" six-bar quotation from the concerto in Act II of the opera when Naisi sings the words: "Having each other and long years before us to make our lives together" (Clarke 1983:

${ }^{8}$ See Bryant 1972: 95, 124, 130 and Bryant 1982: 18, where Ysobel is identified as Margaret Drynan. See also Clarke 1983: 37-38, 212.

${ }^{9}$ I wish to thank Margaret Drynan for her friendly telephone conversation and for providing me with personal information. 
128-9). This was no doubt a code of some sort. Willan, ever the lover of puns and limericks, was said to have enjoyed secret messages of the Elgarian type ${ }^{10}$ The plot thickens in that one of the love songs of 1941, "My Love in Her Attire Doth Show Her Wit," was revised on 26-27 March, 1944 - two days after the completion of the piano concerto. Willan now replaced the original initial chord in the song with the theme of the piano concerto - surely symbolic - and wrote at the head of the manuscript: "With thought as is becoming to my dear" (Clarke 1983: 212). If "Ysobel" helped to inspire the leitmotifs of Deirdre and Agnes the writing out of the opera, what was Corinne's role? Time is so quickly erasing all traces of the secret that we may never know.

Perhaps we should now examine the inscribed copy of the libretto to see what it may reveal about the composer and his work. What are the thirty-six musical excerpts so carefully written out by Willan? Are these all leitmotifs? It is interesting that Clarke, in his comprehensive 1983 biography on Willan, has identified seven main leitmotifs from the opera (Clarke 1983: 126-27, ex. 10511), while Dorith Cooper, in her 1983 doctoral dissertation "Opera in Montreal and Toronto: A Study of Performance Tradition and Repertoire in 1783-1980," has identified twenty-six (Cooper 1983: 1119-76). Time and space do not permit detailed comparisons here, but since, as far as is known, Willan did not leave any other key to the identity of the leitmotifs in this opera - and we have already seen how important he considered this writing technique for Deirdre - a cursory examination is justified. ${ }^{11}$

The illustration shows the opening of Act I and Willan's identification of the first five leitmotifs of the opera. The motif created by lento strummed chords in the upper lefthand margin belongs to the "Bard," while those directly below are in turn associated with "Conochar" and "prophecy." The upper righthand margin contains "Deirdre's" motif and below it the motif of "foreboding." I prefer Clarke's use of terms to Cooper's because his wording is more direct and to the point, and also more descriptive of the mood of the motif: "foreboding" seems a better label than "night of violent storm," especially as this motif does not appear at subsequent appearances of "storms" in the text. Willan's identifications are in general lengthier than Clarke's and the rhythms are at times quite different. (Willan was working from the original short score of the opera, before

\footnotetext{
${ }^{10}$ I wish to thank Margaret Harmer for this information.

11 Because I only had available for examination the tapes of the 1946 and 1951 radio broadcasts and the piano-vocal score of the revised version Deirdre (Scarborough, Ont.: Berandol Music, 1972), I was unable to identify to my complete satisfaction all thirty-six excerpts. A thorough study would entail comparing these passages with the manuscripts in the National Library.
} 
it was orchestrated, while Clarke took his leitmotifs from the later revised version.) Clarke distinguishes between a basic four-note motif for Deirdre and an extended "Deirdre in her love for Naisi" theme, which ends differently from the excerpt written out by Willan. Clarke suggests that "perhaps, since Deirdre and Naisi are usually together, Willan thought the extension of the Deirdre motif sufficient for Naisi" (Clarke 1983: 127). However, Willan writes out two falling fourths in the margin on page seventeen where Deirdre sings "Naisi, Naisi," and since this falling interval occurs frequently at the mention of Naisi's name, this may be an indication that Naisi also had his own leitmotif.

"Cathva's" leitmotif is inscribed by Willan on page two as the incipit of this Druid priest's aria "Blow low, red wind from the east." Willan also writes out the openings of other important aria-like passages in the opera, including both variations of Deirdre's love-lilt "Ah-ah's" and her song "By the whin bush on the mountain," as well as two appearances of Conochar's "Oh, little white doe of the woods of Fuah" (Act II Scene 1 and Act III Scene 1). Strictly speaking, these ariosos are not leitmotifs (they are not considered as such by Clarke), but Willan identifies them in the margins, no doubt because of their musical and dramatic importance. The "tragic fate" motif does not appear until page nine of the libretto, where it is written out in combination with the "prophecy" motif at the text "the curse of the high gods." On page six Willan has written out a fortissimo tremolo motif next to the words "The answer of the gods!" (omitted from the revised version), and on page seven he includes a motif which occurs frequently in this scene, scored for brass, but which is not identified by Clarke or Cooper. It follows the words "when Nessa bore me" and may be termed "gods' plotting." Willan also writes out the musical passage which accompanies the words "a web the gods are weaving" on page eighteen of the libretto, as well as the dissonant chords which follow the text "The gods have spoken!" at the end of the opera. It appears from these excerpts that Willan wished to emphasize the dramatic importance of the gods - of "the implacable fates" - in the opera's story.

It is interesting that Willan includes only fifteen of the twenty-six leitmotifs later identified by Cooper. In addition to the seven main motifs and the four arioso passages discussed above, Willan's list substantiates Cooper's only in the "bird calls" (or "dusk") motif from Act I, Scene 2 (her No. 10), "brooding Conochar" of the Act III orchestral introduction (No. 22), the oboe tune "premonitions" of Deirdre's lament (No. 24) and the "Red Branch pledge" motif from Act III, Scene 2 (No. 25). Cooper does not single out the various "gods' plotting" motifs discussed above, and many of her motifs, such as the tritone figure of "Levercham's fear" (No. 12), the two-note sighs of the "yearning" motif (No. 16), the various chromatic descending harmonies of the "Death" motif (No. 17) and the new 
tritone figure of the "women in fear" motif (No. 26) are standard affective devices which perhaps do not warrant the label of leitmotif. Willan seems particularly interested in identifying significant dramatic moments, as when the fighters bang at Levercham's door near the end of Act II, or when the keening women cry "Ohone" in the opera's final scene. He also writes out certain descriptive motifs, such as a "fighters" motif in Act II, Scene 1, the violin-solo motif depicting the "crystal stone" in Act II, Scene 2 (an episode omitted in the revised version) and a "flight" motif at the end of this scene.

This keyed libretto also provides a further glimpse into Willan's personal life. Among the thirty-six excerpts there is a curious series which does not appear to function as leitmotifs or have dramatic significance, but which may be interpreted as a code of some sort-for Corinne? These excerpts occur at the beginning of Act II, and are set to the following lines of text: "A creature of such shining loveliness"; "a voice calling my name!'; "Hold me close and kiss me once more"; "having each other and long years before us to make our lives together"; "Tomorrow: oh, Naisi, maybe it will be too late"; and perhaps also "Betrothed" (the last passage does not appear in the piano-vocal score). The fourth excerpt, at the words "to make our lives together," is taken from the "Agnes Butcher" piano concerto quotation. The romantic plot has thickened, but unfortunately the trail has become cold. Did Willan deliberately leave such enigmatic clues for later historians to unravel?

A more in-depth study, in particular a comparison of these excerpts with the original manuscript of the opera now in the National Library, would undoubtedly reveal further insight into the work. It is clear that this key in Willan's own hand gives the composer's personal view of what is most important both musically and dramatically in the opera. It may also provide clues to the compositional process of the work. For example, it would appear from the order of leitmotifs on page one that the idea to open the opera with the "foreboding" motif was an afterthought. Also, Clarke's suggestion that the choral "Song of the Clansmen" at the beginning of Act III; Scene 2, with its Irish folk music flavour, was a later addition, seems to be borne out by the lack of an incipit in this inscribed copy of the libretto. Perhaps this remarkable work of one of Canada's greatest composers will be deemed worthy one day of the kind of compositional process study which has now been undertaken for so many composers.

\section{REFERENCES}

ANTHOLOGY OF CANADIAN MUSIC: HEALEY WILLAN.

1982: Radio Canada International. 
BONNET, JOSEPH.

1941: Oxford University Press Music Bulletin, February.

BRYANT, GILES.

1972: Healey Willan Catalogue. Ottawa: National Library of Canada.

1982: Healey Willan Catalogue: Supplement. Ottawa: National Library of Canada.

CHATELIN, RAY.

1991: "Romance, American Style," The Vancouver Province, Friday, June 14, p. 28.

CLARKE, F.R.C.

1983: Healey Willan: Life and Music. Toronto: University of Toronto Press.

COOPER, DORITH RACHEL.

1983: "Opera in Montreal and Toronto: A Study of Performance Traditions and Repertoire 1783-1980. Ph.D. dissertation, University of Toronto.

COULTER, JOHN.

1944: Deirdre of the Sorrows. Toronto: Macmillan.

1980: In My Day: Memoirs. Willowdale, Ont.: Hounslow Press.

LITTLER, WILLIAM.

1966: "Sincere, Honest Deirdre Earns Respect," Toronto Daily Star, September 26.

OPERA CANADA.

1966: “Deirdre," Opera Canada 7/3 (September): 31.

RIDOUT, GODFREY.

1959: “Healey Willan," The Canadian Music Journal 3: 9-10.

WILLAN, HEALEY.

1946: CBC radio broadcast of Deirdre of the Sorrows, April 20. (Tapes provided by Peter Haworth.)

1951: CBC Opera Company broadcast of Deirdre of the Sorrows, October 10, intermission talk. (Transcribed from tapes provided by the Canadian Music Centre.)

1966: CBCRadio “Tuesday Night" broadcast of Deirdre, October 11, intermission talk.

1972: Deirdre. Piano-vocal score. Scarborough, Ont.: Berandol Music. 